\title{
One-Shot Synthesis of Peptide Amphiphiles with Applications in Directed Graphenic Assembly
}

\author{
Karoline E. Eckhart, ${ }^{\dagger, \S}$ Francesca A. Starvaggi, ${ }^{\dagger},{ }^{\dagger}$ Stefanie A. Sydlik ${ }^{* \dagger}$ \\ ${ }^{\dagger}$ Department of Chemistry, Carnegie Mellon University, Pittsburgh, PA, USA \\ ${ }^{\S}$ Authors contributed equally
}

\section{Supplementary Information}

\begin{tabular}{|c|}
\hline$*$ Corresponding Author \\
\hline Professor Stefanie A. Sydlik \\
Department of Chemistry \\
Carnegie Mellon University \\
4400 Fifth Avenue \\
Pittsburgh, PA 15213, United States \\
\hline
\end{tabular}




\section{Table of Contents}

1. Materials ................................................................... 3

2. Instrumentation $\ldots \ldots \ldots \ldots \ldots \ldots \ldots \ldots \ldots \ldots \ldots \ldots \ldots \ldots \ldots \ldots \ldots \ldots \ldots \ldots \ldots \ldots \ldots \ldots \ldots \ldots \ldots \ldots \ldots, 4$

3. Synthetic Methods.................................................. 4-7

Scheme S1

Scheme S2

4. ${ }^{1} \mathrm{H}-\mathrm{NMR}$ Kinetics........................................................ 8-11

Figure $\mathrm{S} 1$

4.1 Data processing

Figure S2

4.2 Calculation of experimental parameters for Mayo-Lewis fitting

4.3 Mayo-Lewis non-linear fitting

Figure S3

5. Material Characterization Methods

$12-15$

5.1 Determination of copolypeptide composition

Figure S4

5.2 Determination of length of discrete $p($ Leu $)$ block

Figure S5

Table $\mathrm{S} 1$

5.3 Determination of PA-G/PA composition

Figure S6

6. Supplemental Results

Figure S7

Figure S8

Figure S9

Figure S10

Figure S11

Figure S12

Figure S13

7. Bacterial Studies.

7.1 Bacterial culture

7.2 Data Analysis

7.3 Statistical Analysis

8. References 


\section{MATERIALS}

$\mathrm{N}_{6}$-carbobenzyloxy-L-lysine and L-Leucine were purchased from Chem-Implex International and Advanced ChemTech, respectively. Potassium ethyl xanthogenate was purchased from EMD Millipore. Triphosgene was purchased from TCI America. Hexylamine, triethylorthoacetate, thionyl chloride, and phosphorous trichloride were purchased from Aldrich. Natural flake graphite (-325 mesh, 99.8\% metal basis), trifluoracetic acid, and hydrobromic acid (48\% w/w aqueous) were purchased from Alfa Aesar. Glacial acetic acid was purchased from Fisher Chemical. These chemicals were used as purchased, without further purification. Dry tetrahydrofuran was obtained directly from a dry solvent still. Dioxane and dimethylformamide were dried by passing through a column of activated alumina followed by purging with nitrogen for 20 min. FM-4-64 dye was purchased from Life Technologies (Thermo Fisher). SnakeSkin dialysis tubing with a $3.5 \mathrm{kDa}$ molecular weight cutoff was purchased from Thermo Fisher.

\section{INSTRUMENTATION}

Nuclear Magnetic Resonance (NMR)

A $500 \mathrm{MHz}$ NMR (Bruker Avance ${ }^{\mathrm{TM}}$ 500) was used to acquire ${ }^{1} \mathrm{H}-\mathrm{NMR}$ spectra. Data was analyzed using Mestrenova software (version 12.0.1).

\section{Gel Permeation Chromatography (GPC)}

Polypeptide solutions (approximately $10 \mathrm{mg} / \mathrm{mL}$ in dimethylformamide, filtered through a $0.2 \mu \mathrm{m}$ PTFE membrane) were analyzed via gel permeation chromatography with dimethylformamide at $25^{\circ} \mathrm{C}$ as eluent with a constant flow rate of $1.00 \mathrm{~mL} / \mathrm{min}$. A differential refractive index (RI) detector (Waters and Wyatt) was used, and spectra were calibrated to poly(methyl methacrylate) standards.

\section{Microscopy (copolypeptides)}

To assess neat copolypeptide assembly, deprotected PAs (peptide amphiphiles) were dissolved in a $1 \% \mathrm{w} / \mathrm{v}$ solution of $99 \%$ DI $\mathrm{H}_{2} \mathrm{O}$ with $1 \%$ v/v TFA.

To assess PA-G/PA (peptide amphiphile-graphenic conjugate materials) assembly, $15 \mathrm{mg}$ of PAG/PA was dispersed in $300 \mu \mathrm{L}$ of THF via sonication for 3 min. Then, $700 \mu \mathrm{L}$ of $\mathrm{DI} \mathrm{H}_{2} \mathrm{O}$ was added, dropwise, along with $3 \mu \mathrm{L}$ of TFA. Overall, this gives $1.5 \mathrm{wt}$ \% PA-G/PA in a solution of $30 \%$ THF, $69 \%$ DI $\mathrm{H}_{2} \mathrm{O}, 1 \%$ TFA. This solution was visualized via microscopy, with and without FM-4-64 dye.

As a control, a noncovalent blend of PA with sCG (graphenic synthesis described below) prepared by dispersing $0.68 \mathrm{mg}$ of sCG and $55.94 \mathrm{mg}$ of one-shot PA (p(Lys) $)_{80}-b$-p (Leu $\left.)_{30}\right)$ in $1132.4 \mu \mathrm{L}$ of THF via sonication for $3 \mathrm{~min}$. Then, $2642.2 \mu \mathrm{L}$ of $\mathrm{DI} \mathrm{H}_{2} \mathrm{O}$ were added dropwise along with $37 \mu \mathrm{L}$ of TFA. Overall, this gives 1.5 wt. \% PA+sCG in a solution of 30\% THF, 69\% DI $\mathrm{H}_{2} \mathrm{O}, 1 \%$ TFA.

To $50 \mu \mathrm{L}$ of PA or PA-G/PA solution was added $0.1 \mu \mathrm{L}$ of FM-4-64 dye solution $(0.5 \mu \mathrm{g} / \mu \mathrm{L}$ in DMSO, excitation $558 \mathrm{~nm}$, emission $734 \mathrm{~nm}$ ). Assemblies were visualized using an EVOS ${ }^{\circledR} \mathrm{FL}$ 
Auto Cell Imaging System (ThermoFisher Scientific) with a 40×, 0.65 numerical aperture objective or $10 \times, 0.25$ numerical aperture objective. Fluorescence images were acquired using the RFP light cube (531/40 Ex; 593/40 Em).

\section{Fourier Transform Infrared (FTIR) Spectroscopy}

FTIR attenuated total reflectance spectroscopy was performed using a PerkinElmer Frontier FTIR spectrometer with a germanium crystal. Spectra were acquired with a $0.25 \mathrm{~cm}^{-1}$ resolution over a range of 700-4000 $\mathrm{cm}^{-1}$. Using the Spectrum software (PerkinElmer), spectra were corrected for attenuated total reflectance mode, converted to absorbance, and normalized to the local maxima between 1536 and $1574 \mathrm{~cm}^{-1}$.

\section{Thermogravimetric Analysis (TGA)}

TGA was performed using a PerkinElmer TGA 4000 with Pyris Software. Samples were run under nitrogen with a flow rate of $20 \mathrm{~mL} \mathrm{~min}^{-1}$. Samples (approximately $5 \mathrm{mg}$, ground into a fine powder) were heated from $50-800^{\circ} \mathrm{C}$ at a rate of $10^{\circ} \mathrm{C} \mathrm{min}{ }^{-1}$, and the mass was monitored with a step size of $0.17^{\circ} \mathrm{C}$. The data was analyzed using TRIOS software (TA Instruments).

\section{Plate Reader}

To assess antimicrobial activity of the one shot PAs, absorbance and fluorescence measurements were acquired using a Spark Multimode Microplate Reader (TECAN). Absorbance spectra were acquired at $670 \mathrm{~nm}$ at $23{ }^{\circ} \mathrm{C}$, with 10 flashes and a settle time of $50 \mathrm{~ms}$. Fluorescence spectra were acquired at an excitation wavelength of $485 \mathrm{~nm}$ and an emission wavelength of $530 \mathrm{~nm}$ at $26{ }^{\circ} \mathrm{C}$, with 30 flashes and an integration time of $40 \mu \mathrm{s}$.

\section{SYNTHETIC METHODS}

Synthesis of S-Ethoxythiocarbonyl Mercaptoacetic Acid (XAA)

The synthesis of XAA was adapted from a previously published protocol. ${ }^{1} \mathrm{NaOH}(0.8418 \mathrm{~g}, 33.59$ mmol, $1.7 \mathrm{eq}$ ) was dissolved in $140 \mathrm{~mL}$ of $\mathrm{DI} \mathrm{H}_{2} \mathrm{O}$. Chloroacetic acid was added $(1.9000 \mathrm{~g}, 20.11$ mmol, $1 \mathrm{eq})$ followed by potassium ethyl xanthogenate $(3.5410 \mathrm{~g}, 22.09 \mathrm{mmol}, 1.1 \mathrm{eq})$. The reaction was stirred at ambient temperature for $24 \mathrm{~h}$. The reaction solution was then acidified to $\mathrm{pH} 1$ with concentrated $\mathrm{HCl}$, which resulted in a white precipitate. The solution was extracted with dichloromethane (4 X $50 \mathrm{~mL}$ ). The presence of XAA in the organic layer was confirmed by thin layer chromatography (TLC) $\left(\mathrm{R}_{\mathrm{f}}=0.56,100 \%\right.$ ethyl acetate). The organic layer was then dried over $\mathrm{MgSO}_{4}$, filtered, and evaporated to dryness to give crude XAA as a white solid. The white solid was recrystallized in hexane to give long, needle shaped crystals $(2.1671 \mathrm{~g}, 59 \%$ yield). Structure was confirmed by ${ }^{1} \mathrm{H}-\mathrm{NMR}\left(500 \mathrm{MHz}, \mathrm{DMSO}-\mathrm{d}_{6}\right) \delta \mathrm{ppm}: 4.68\left(\mathrm{q}, 2 \mathrm{H}, \mathrm{CH}_{2}\right), 3.99$ (s, $\left.2 \mathrm{H}, \mathrm{CH}_{2}\right), 1.45\left(\mathrm{t}, 3 \mathrm{H}, \mathrm{CH}_{3}\right)$.

Synthesis of $N_{\varepsilon}$ Carbobenzyloxy-L-lysine $N$-carboxyanhydride (Lys(Z)-NCA)

The synthesis of Lys(Z)-NCA was adapted from a previously published protocol. ${ }^{1} \mathrm{H}-\mathrm{Lys}(\mathrm{Z})-\mathrm{OH}$ (4.205 g, $15.0 \mathrm{mmol}, 1 \mathrm{eq}$ ) was added to an oven-dried flask and vacuum-backfilled thrice with 
$\mathrm{N}_{2}$. The amino acid was then dispersed in $150 \mathrm{~mL}$ of dry THF. Triphosgene $(2.221 \mathrm{~g}, 7.5 \mathrm{mmol}$, 0.5 eq) was added in one shot under a continuous flow of $\mathrm{N}_{2}$, and the mixture was reacted at $50^{\circ} \mathrm{C}$ for $4 \mathrm{~h}$. The mixture was then evaporated to dryness to give a beige solid. The solid was redissolved in ethyl acetate, then sequentially washed with a mixture of $5 \% \mathrm{HCl}$ and ice $(3 \mathrm{X} 50$ $\mathrm{mL})$. The presence of Lys(Z)-NCA in the organic layer was confirmed by TLC $\left(\mathrm{R}_{\mathrm{f}}=0.93,100 \%\right.$ ethyl acetate). The organic layer was then dried over $\mathrm{MgSO}_{4}$ and filtered through a silica plug into a flame-dried round bottom flask. The solution was evaporated to dryness to give a white powder (3.634 g, $11.86 \mathrm{mmol}, 79 \%$ yield) which was stored at $4{ }^{\circ} \mathrm{C}$. The structure and purity were confirmed by ${ }^{1} \mathrm{H}-\mathrm{NMR}$ (Figure S7).

\section{Synthesis of L-Leucine N-Thiocarboxyanhydride (Leu-NTA)}

The synthesis of Leu-NTA was adapted from a previously published protocol. ${ }^{1} \mathrm{NaOH}(445.0 \mathrm{mg}$, $11.15 \mathrm{mmol}, 2 \mathrm{eq}$ ) was dissolved in $18 \mathrm{~mL}$ of DI $\mathrm{H}_{2} \mathrm{O}$. H-Leu-OH (729.7 mg, $\left.5.56 \mathrm{mmol}, 1 \mathrm{eq}\right)$ was added followed by XAA $(1.002 \mathrm{~g}, 5.56 \mathrm{mmol}, 1 \mathrm{eq})$. The mixture was stirred vigorously at ambient temperature for 3 days. The reaction solution was then acidified to $\mathrm{pH} 3$ with concentrated $\mathrm{HCl}$ and extracted with ethyl acetate $(3 \times 50 \mathrm{~mL})$. The presence of Leu-XAA in the organic layer was confirmed by TLC $\left(\mathrm{R}_{\mathrm{f}}=0.9,100 \%\right.$ ethyl acetate). The organic layer was then dried over $\mathrm{MgSO}_{4}$, filtered into a flame-dried round-bottom flask, and evaporated to dryness. The residue was then re-dissolved in $11 \mathrm{~mL}$ of dry THF. $\mathrm{PCl}_{3}$ was added, dropwise, to the solution under $\mathrm{N}_{2}$. After reacting at room temperature for $24 \mathrm{~h}$ (under $\mathrm{N}_{2}$ ), the reaction mixture was cut with $50 \mathrm{~mL}$ of ice cold $50 / 50$ ethyl acetate/ $\mathrm{NaHCO}_{3}$, then sequentially washed with $5 \% \mathrm{HCl}(50 \mathrm{~mL})$, saturated $\mathrm{NaHCO}_{3}(50 \mathrm{~mL})$, and brine $(50 \mathrm{~mL})$ - all with ice. The presence of Leu-NTA in the organic layer was confirmed by TLC $\left(R_{f}=0.96,100 \%\right.$ ethyl acetate). The organic layer was then dried over $\mathrm{MgSO}_{4}$, filtered, and evaporated to dryness to give an off-white powder $(685.6 \mathrm{mg}, 3.958 \mathrm{mmol}$, $71 \%$ yield), stored at $4{ }^{\circ} \mathrm{C}$. The structure and purity were confirmed by ${ }^{1} \mathrm{H}-\mathrm{NMR}$ (Figure S8).

Synthesis of $s C G$

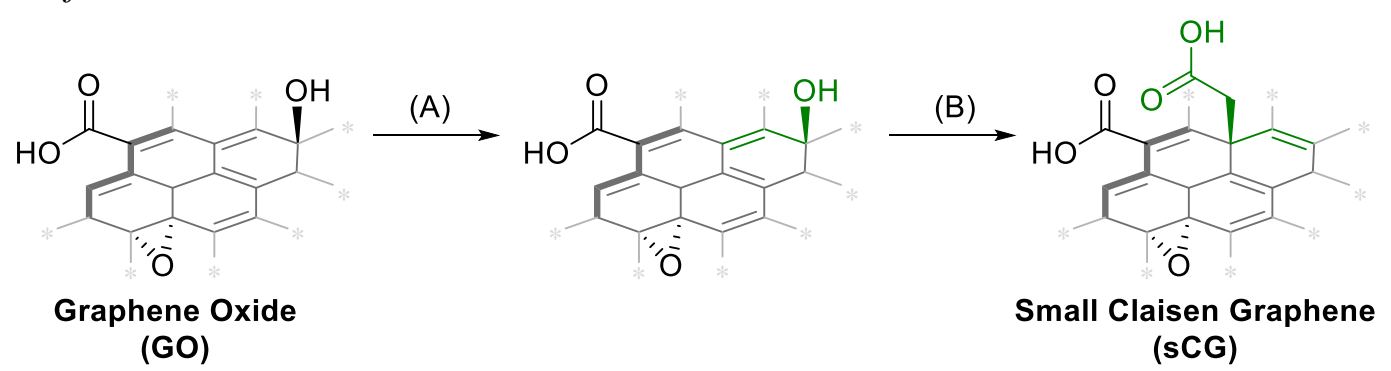

Scheme S1. Synthesis of small Claisen graphene (sCG) from graphene oxide (GO). (A) Sonicate for 10 hours in triethylorthoacetate to reduce particle size. (B) Claisen rearrangement, followed by saponification. In this scheme, the GO flake is represented by a pyrene, where the edge of the flake (containing carboxylic acid functional groups) is bolded and the basal plane (containing epoxide and alcohol functional groups) extends beyond to depicted structure as indicated by asterisks $\left({ }^{*}\right)$. 
First, graphene oxide (GO) was synthesized from graphite using a modified Hummer's method, giving particles with a z-average diameter of $2.4 \pm 1.4 \mu \mathrm{m}$ by dynamic light scattering (Zetasizer Nano ZS, Malvern Instruments Ltd.). Small Claisen Graphene (sCG) was synthesized from a modified procedure developed by our group. ${ }^{2} \mathrm{GO}(109.9 \mathrm{mg})$ was added to a flame-dried round bottom then sonicated for $10 \mathrm{~h}(240 \mathrm{~W}, 42 \mathrm{kHz}$, ultrasonic cleaner, Kendal $)$ in $20 \mathrm{~mL}$ of triethylorthoacetate. Following sonication, the solution was transferred to a $50 \mathrm{~mL}$ conical centrifuge tube and centrifuged at $750 \times g \quad 15 \mathrm{sec}$. The pellet was rinsed twice with acetone and dried under vacuum to give a mass of $90.5 \mathrm{mg}$, indicating that approximately $19.4 \mathrm{mg}$ of GO remained dispersed in the supernatant. The supernatant, which contained GO with small particle sizes, was poured back into the round bottom along with p-toluene sulfonic acid (5.5 mg). The reaction solution was refluxed at $140{ }^{\circ} \mathrm{C}$ for $36 \mathrm{~h}$. The reaction was then removed from heat, a solution of $1 \mathrm{M} \mathrm{NaOH}(13.2 \mathrm{~mL})$ was added to saponify the material, and the reaction was stirred for another $12 \mathrm{~h}$. Next, the reaction solution was centrifuged $12,500 \times \mathrm{g}$ for $15 \mathrm{~min}$, which pelleted sCG. The supernatant was discarded. The sCG was rinsed twice with acetone, then was redispersed in dry dioxane $(5 \mathrm{~mL})$ and used immediately for sECG (small electrophilic Claisen graphene) synthesis. sCG has particles with a z-average diameter of $0.62 \pm 0.16 \mu \mathrm{m}$ by dynamic light scattering (DLS).

Synthesis of $P A-G / P A$

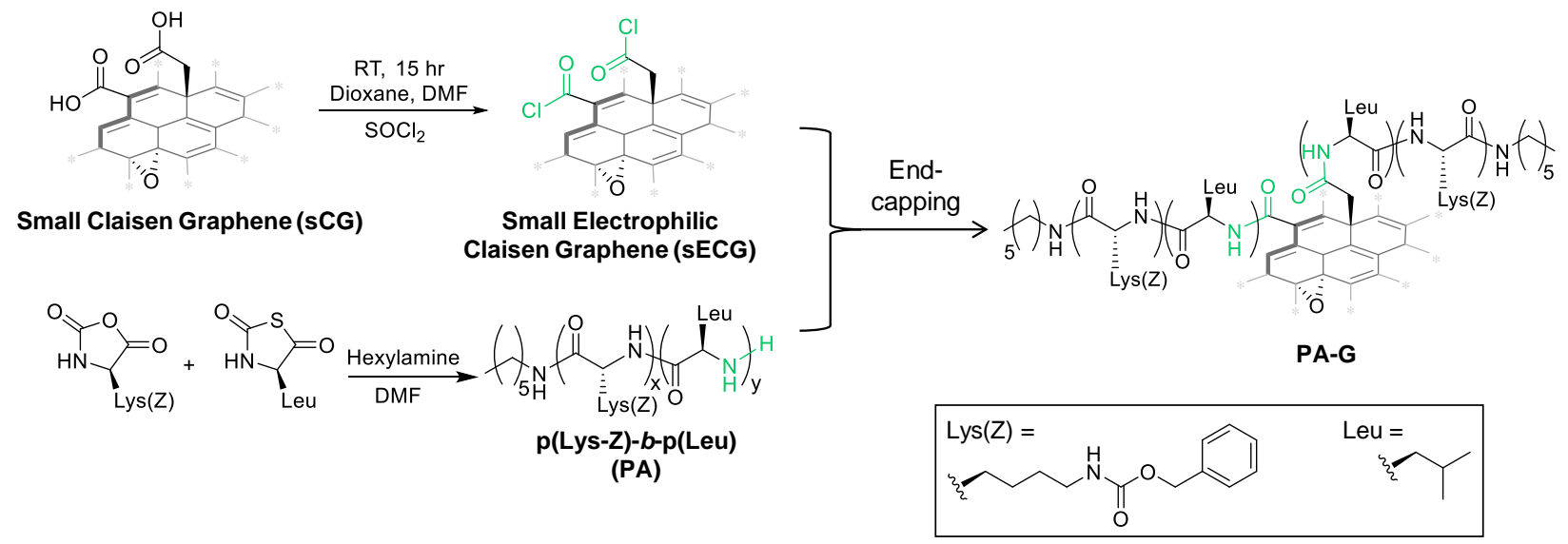

Scheme S2. One-shot block copolypeptide (p(Lys-Z)- $b$-p(Leu)) is end-capped with electrophilic sCG to give a covalently conjugated peptide amphiphile-graphene (PA-G). The molar excess of $\mathrm{p}($ Lys-Z)- $b$ - $\mathrm{p}(\mathrm{Leu})$ compared to electrophilic sCG results in a mixture of covalently bound PA-G with unreacted, unbound $\mathrm{p}(\mathrm{Lys}-\mathrm{Z})-b-\mathrm{p}(\mathrm{Leu}))$. This mixture can be treated with acid to deprotect the lysine residues, giving PA-G/PA.

PA-G was synthesized using a modified polypeptide end-capping procedure developed by our group. ${ }^{3}$ The procedure entails a concurrent synthesis of small Electrophilic Claisen Graphene (sECG) which is used to end-cap a growing on shot block copolypeptide through its nucleophilic amine endgroup. 
A solution of sCG in dry dioxane (approximately $19.4 \mathrm{mg}$ in $5 \mathrm{~mL}$ ) was transferred into an ovendried round bottom and sonicated for $10 \mathrm{~min}$. Then, under a constant flow of $\mathrm{N}_{2}, \mathrm{SOCl}_{2}(0.12 \mathrm{~mL})$ was added dropwise along with dry DMF $(0.06 \mathrm{~mL})$. The reaction was stirred under $\mathrm{N}_{2}$ for $6 \mathrm{~h}$, then centrifuged at $12,500 \times \mathrm{g}$ for $15 \mathrm{~min}$. The supernatant, a clear orange solution, was discarded and the pellet, sECG, was redispersed in DCM $(8 \mathrm{~mL})$ via sonication for $10 \mathrm{~min}$. The sECG dispersion was used immediately for copolypeptide end-capping.

To synthesize the block copolypeptide, an oven-dried round bottom was charged with Lys(Z)NCA (1.5019 g, $4.9029 \mathrm{mmol})$ and Leu-NTA (318.5 mg, $1.8386 \mathrm{mmol})$ and vacuum-backfilled thrice with $\mathrm{N}_{2}$. While maintaining an inert atmosphere, the comonomers were dissolved in dry DMF $(13.6 \mathrm{~mL})$, and the copolymerization was initiated with hexylamine $(0.0613 \mathrm{mmol}$ in a solution of $1.18 \mathrm{~mL}$ of DMF). The copolymerization was stirred under $\mathrm{N}_{2}$ for $5 \mathrm{~min}$, then put under light vacuum (approximately $300 \mathrm{mbar}$ ) and stirred for 3 days. After 3 days, an $1.5 \mathrm{~mL}$ aliquot of the copolymerization solution was precipitated in cold ethyl ether to give $\mathrm{p}($ Lys-Z)- $b$ - $\mathrm{p}(\mathrm{Leu})$ as a white powder $(178.3 \mathrm{mg}$ ). The remaining $13.28 \mathrm{~mL}$ of copolypeptide solution (approximately $1.5845 \mathrm{~g}, 0.0551 \mathrm{mmol}$ ) was end-capped with the dispersion of sECG (approximately $19.4 \mathrm{mg}$ in $8 \mathrm{~mL}$ of DCM). The end-capping was stirred at room temperature for 2 days. The reaction solution was then cut with cold ethyl ether $(80 \mathrm{~mL})$ and centrifuged at $2420 \times g$ for $10 \mathrm{~min}$ to pellet a mixture of free copolypeptide with copolypeptide that is covalently conjugated to $\mathrm{SCG}$, termed "PAG/PA". To purify the composite material, the pellet was dispersed in DMF $(8 \mathrm{~mL})$, reprecipitated in cold ethyl ether $(80 \mathrm{~mL})$, and centrifuged at $2420 \times g$ for $10 \mathrm{~min}$.

\section{Deprotection of PA-G/PA}

Protected PA-G/PA composite $(1.5 \mathrm{~g})$ was dispersed in acetic acid $(26 \mathrm{~mL})$ via sonication for 10 min. Then, $3.6 \mathrm{~mL}$ of TFA and $3.8 \mathrm{~mL}$ of $\mathrm{HBr}\left(48 \%\right.$ in $\left.\mathrm{H}_{2} \mathrm{O}\right)$ were added to the dispersion. The reaction was stirred for $24 \mathrm{~h}$, then neutralized to $\mathrm{pH} 7$ with $6 \mathrm{M} \mathrm{NaOH}$. The reaction mixture was then dialyzed against $\mathrm{DI}_{2} \mathrm{O}$ for 4 days (molecular weight cutoff of $3.5 \mathrm{kDa}$ ), then lyophilized to dryness.

Synthesis of pLys(Z)-b-pLeu via Sequential Monomer Addition

An oven-dried round bottom was charged with Lys(Z)-NCA (1.5019 g, $4.9029 \mathrm{mmol})$ and vacuum-backfilled thrice with $\mathrm{N}_{2}$. While maintaining an inert atmosphere, the monomer was dissolved in dry DMF $(9.67 \mathrm{~mL})$, and the polymerization was initiated with hexylamine $(0.0613$ mmol in a solution of $1.13 \mathrm{~mL}$ of DMF). The polymerization was stirred under $\mathrm{N}_{2}$ for $5 \mathrm{~min}$, then put under light vacuum (approximately $300 \mathrm{mbar}$ ) and stirred for 2 days. Then, the reaction was refilled with $\mathrm{N}_{2}$ and Leu-NCA ( $288.97 \mathrm{mg}, 1.8386 \mathrm{mmol}$ ) was added to the polymerization in a solution of $4.00 \mathrm{~mL}$ of dry DMF. The polymerization was stirred under $\mathrm{N}_{2}$ for $5 \mathrm{~min}$, then put under light vacuum (approximately $300 \mathrm{mbar}$ ) and stirred overnight. To isolate the neat copolypeptide, the reaction solution was then cut with cold ethyl ether and centrifuged at $2420 \times g$ for $10 \mathrm{~min}$. The resulting block copolypeptide was analyzed by GPC (Figure S9). Alternatively, the copolypeptide could be end-capped with sECG as previously described. 


\section{4. ${ }^{1} \mathrm{H}-\mathrm{NMR}$ KINETICS}

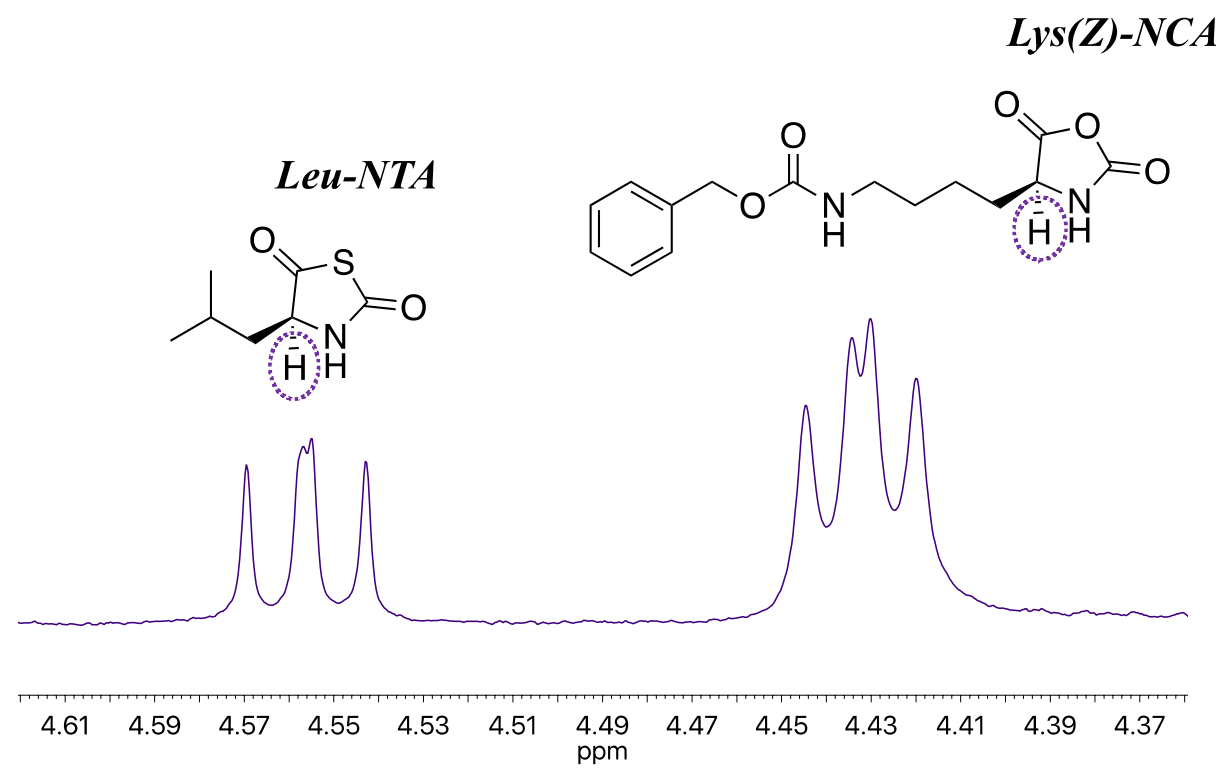

Figure S1. Sample ${ }^{1} \mathrm{H}-\mathrm{NMR}$ spectrum (500 MHz, DMSO-d $\mathrm{d}_{6}$ ) of a copolymerization kinetics aliquot displaying both comonomer peaks. The Lys(Z)-NCA (4.405 - $4.460 \mathrm{ppm})$ and Leu-NTA $(4.535-4.580 \mathrm{ppm})$ absolute peak integrations (normalized to the DMF peak between 7.860 $8.000 \mathrm{ppm})$ can be compared across reaction aliquots to quantify monomer concentration at various time points.

\subsection{Data processing}

Due to the absence of chain terminating events at the beginning of the reaction, the copolymerizations herein follow first order kinetics which can be represented by the following linear equation:

$$
\ln \left(\frac{[\mathrm{M}]_{\mathrm{o}}}{[\mathrm{M}]_{\mathrm{i}}}\right)=\mathrm{k}_{\mathrm{obs}}[\mathrm{I}] \mathrm{t}
$$

$[\mathrm{M}]_{0}=$ initial monomer concentration; $[\mathrm{M}]_{\mathrm{i}}=$ instantaneous monomer concentration; $\mathrm{k}_{\mathrm{obs}}=$ apparent rate constant; $[\mathrm{I}]=$ initiator concentration; $\mathrm{t}=$ time

As such, semilogarithmic plots of $\ln \left([\mathrm{M}]_{0} /[\mathrm{M}]_{\mathrm{i}}\right)$ versus time were constructed for each monomer (Figure S2A, S2C, S2E) and for the sum of the comonomers (Figure S2B, S2D, S2F, S2G, S2H). These plots were fitted to a linear regression where the following is true:

$$
\mathrm{k}_{\mathrm{obs}}=\frac{\text { slope of semilog plot }}{[\mathrm{I}]}
$$



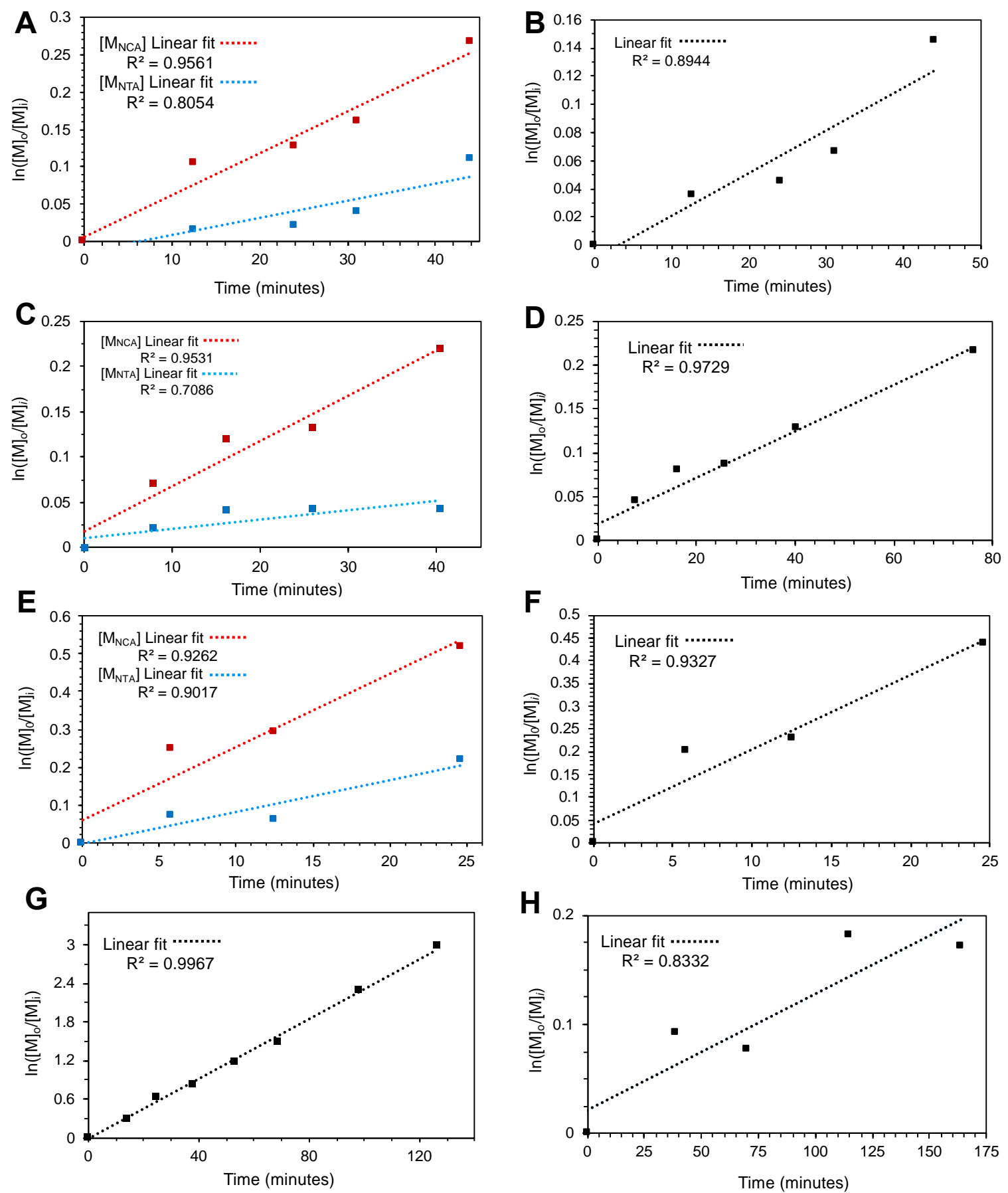

Figure S2. Semilogarithmic, first order kinetics plots with linear fitting. Data is shown for the beginning of the copolymerizations, where the reaction follows first order kinetics. Graphs $\mathbf{A}, \mathbf{C}$, and $\mathbf{E}$ represent comonomer conversion, while graphs $\mathbf{B}, \mathbf{D}, \mathbf{F}, \mathbf{G}$, and $\mathbf{H}$ represent total monomer conversion. A \& B) $f_{N C A}=0.75,\left[\mathbf{M}_{\text {total }}\right]_{o}:[\mathrm{I}]=70 . \mathbf{C} \&$ D) $f_{N C A}=0.5$, $\left.\left[\mathbf{M}_{\text {total }}\right]_{\mathrm{o}}:[\mathrm{I}]=70 . \mathbf{E} \& \mathbf{F}\right) f_{N C A}$ $\left.\left.=0.25,\left[\mathrm{M}_{\text {total }}\right]_{\mathrm{o}}:[\mathrm{I}]=50 . \mathbf{G}\right) f_{N C A}=1.0 . \mathbf{H}\right) f_{N C A}=0$. 


\subsection{Calculation of experimental parameters for Mayo-Lewis fitting}

The Mayo-Lewis equation, Equation 3, represents the relationship between copolypeptide composition and comonomer feed ratio:

$$
F_{N C A}=\frac{r_{N C A} f_{N C A}{ }^{2}+f_{N C A} f_{N T A}}{r_{N C A} f_{N C A}{ }^{2}+2 f_{N C A} f_{N T A}+r_{N T A} f_{N T A}{ }^{2}}
$$

Where,

$\mathrm{F}_{\mathrm{NCA}}=$ the molar ratio of the NCA amino acid in the copolypeptide at a given monomer conversion

$\mathrm{f}_{\mathrm{NCA}}$ and $\mathrm{f}_{\mathrm{NTA}}=$ the molar ratio of each of the comonomers at the beginning of the reaction

$\mathrm{r}_{\mathrm{NCA}}$ and $\mathrm{r}_{\mathrm{NTA}}=$ the reactivity ratios of the respective comonomers

$\mathrm{f}_{\mathrm{NCA}}$ and $\mathrm{f}_{\mathrm{NTA}}$ can be calculated using Equations $4 \mathrm{a}$ and $4 \mathrm{~b}$ :

$$
\mathrm{f}_{\mathrm{NCA}}=\frac{[\mathrm{NCA}]_{0}}{[\mathrm{NCA}]_{0}+[\mathrm{NTA}]_{0}} ; \mathrm{f}_{\mathrm{NTA}}=\frac{[\mathrm{NTA}]_{0}}{[\mathrm{NCA}]_{0}+[\mathrm{NTA}]_{0}} \quad \text { (Equations 4a and 4b) }
$$

Where $[\mathrm{NCA}]_{0}$ and $[\mathrm{NTA}]_{0}$ are the initial monomer concentrations, which are experimentally known

Theoretical values for $\mathrm{F}_{\mathrm{NCA}}$ were determined using Equation 3 in conjunction with the experimental values of $f_{\mathrm{NCA}}$ and $\mathrm{f}_{\mathrm{NTA}}$ and arbitrarily chosen values for $\mathrm{r}_{\mathrm{NCA}}$ and $\mathrm{r}_{\mathrm{NTA}}$. This gave a theoretical data set of F $_{\mathrm{NCA}, \mathrm{Th}}$ versus $\mathrm{f}_{\mathrm{NCA}}$.

To calculate experimental values of $\mathrm{F}_{\mathrm{NCA}}$, we chose to focus on $10 \%$ total monomer conversion, because all copolymerizations were well within the linear range of the first order kinetic plot, indicating an absence of chain terminating events at this conversion. The following set of equations describe how copolypeptide composition at $10 \%$ conversion, $\mathrm{F}_{\mathrm{NCA} \text {,Exp }}$, was derived from the linear regression of the first order kinetic plots from Figure S2 (indicated with the subscript "semilog, total monomer" or "semilog, NCA"). This calculation was performed for each experimental monomer feed ratio $\left(f_{\mathrm{NCA}}\right)$ :

Calculation 5a: determination of time at 10\% total monomer conversion (derived from Equation 1)

$$
\mathrm{t}_{10 \%, \text { total }}=\frac{\ln \left(\frac{100}{90}\right)+\text { intercept }_{\text {semilong,total monomer }}}{\text { slope }_{\text {semilog,total monomer }}}
$$

Calculation 5b: determination of individual monomer consumption at $10 \%$ total monomer conversion (derived from Equation 1)

$$
\begin{gathered}
{[\mathrm{NCA}]_{10 \%, \text { total }}=[\mathrm{NCA}]_{0} \times \mathrm{e}^{-\left(\mathrm{t}_{10 \%, \text { total }} \times \text { slope }_{\text {semilog,NCA }}\right)}} \\
{[\mathrm{NCA}]_{\text {consumed }}=[\mathrm{NCA}]_{0}-[\mathrm{NCA}]_{10 \%, \text { total }}}
\end{gathered}
$$


Calculation 5c: determination of copolypeptide composition (ratio of NCA amino acid, $F_{N C A}$ ) at $10 \%$ total monomer conversion. Note that use of $[\mathrm{NCA}]_{\text {consumed }}$ assumes that all NCA consumption is due to propagation into the copolypeptide.

$$
\mathrm{F}_{\mathrm{NCA}, \exp }=\frac{[\mathrm{NCA}]_{\text {consumed }}}{[\mathrm{NCA}]_{\text {consumed }}+[\mathrm{NTA}]_{\text {consumed }}}
$$

The experimentally determined copolypeptide compositions $\left(\mathrm{F}_{\mathrm{NCA}, \mathrm{exp}}\right)$ were used in conjunction with experimental values of $\mathrm{f}_{\mathrm{NCA}}$ for Mayo-Lewis non-linear fitting.

\subsection{Mayo-Lewis non-linear fitting}

The values of $\mathrm{f}_{\mathrm{NCA}}, \mathrm{f}_{\mathrm{NTA}}, \mathrm{F}_{\mathrm{NCA}}$,exp, and $\mathrm{F}_{\mathrm{NCA}, \mathrm{Th}}$ were imported into excel and plotted as seen in Figure S3.

$$
\begin{gathered}
\text { Residuals }=\left(\mathrm{F}_{\mathrm{NCA}, \exp }-\mathrm{F}_{\mathrm{NCA}, \mathrm{Th}}\right)^{2} \\
\text { WSSR }=\sum \text { Residuals }
\end{gathered}
$$

Values for $\mathbf{r}_{\mathrm{NCA}}$ and $\mathrm{r}_{\mathrm{NTA}}$ were chosen as 1, arbitrarily, to begin the analysis. Then, the Solver addin in Microsoft Excel was used to optimize the reactivity ratios, $\mathrm{r}_{\mathrm{NCA}}$ and $\mathrm{r}_{\mathrm{NTA}}$ until the values for $\mathrm{F}_{\mathrm{NCA}, \exp }$ (determined from the kinetics experiments) and $\mathrm{F}_{\mathrm{NCA}, \mathrm{Th}}$ (determined using Equation 3) matched each other closely.

\section{A) Data set before Solver}

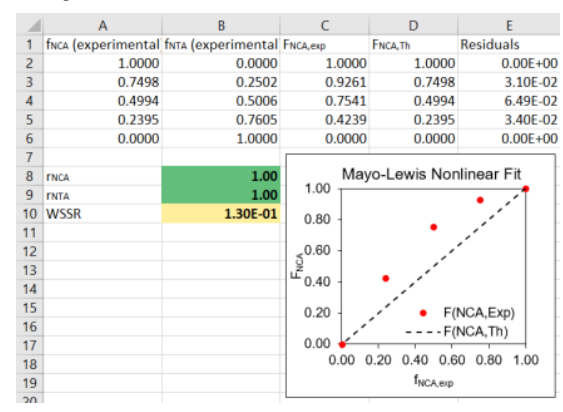

B) Solver dialog box

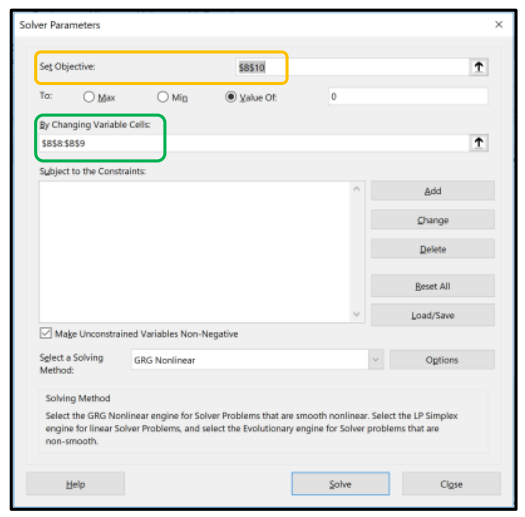

C) Data set after Solver

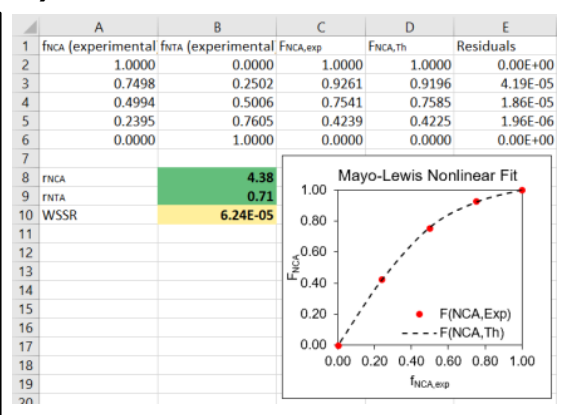

Figure S3. A) Snip of excel sheet before using Solver for nonlinear fitting. Note that, with these

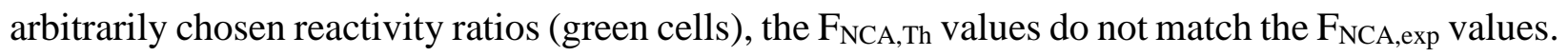
This is seen quantitatively in the relatively high WSSR (yellow box) and qualitatively in the graph where the theoretical fit does not match the experimental data. B) Solver dialog box outlines which parameters were set as the objective (WSSR, yellow box) and variables ( $\mathrm{r}_{\mathrm{NCA}}$ and $\mathrm{r}_{\mathrm{NTA}}$, green box). C) Snip of excel sheet after using Solver for nonlinear fitting. Note that, with the optimized

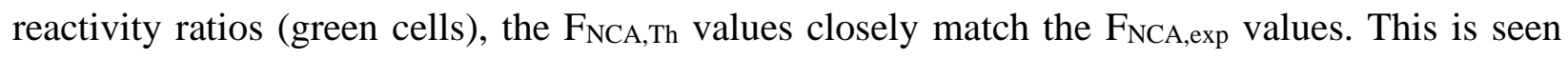
quantitatively in the relatively low WSSR (yellow box) and qualitatively in the graph where the theoretical fit does not match the experimental data. 


\section{MATERIAL CHARACTERICATION METHODS}

\subsection{Determination of Copolypeptide Composition}

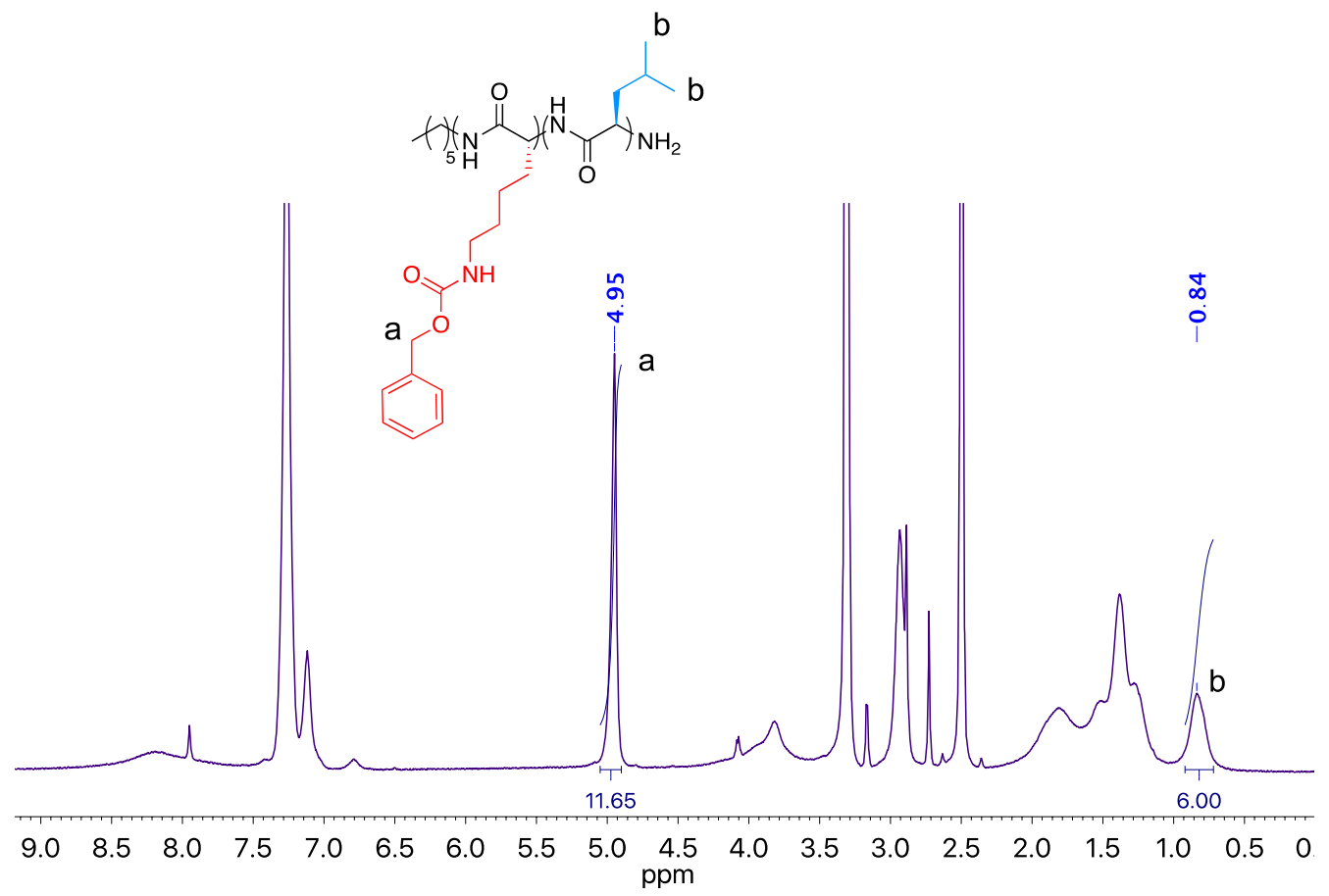

Figure S4. ${ }^{1} \mathrm{H}-\mathrm{NMR}\left(500 \mathrm{MHz}, \mathrm{DMSO}-\mathrm{d}_{6}\right)$ of $\mathrm{p}($ Lys-Z)- $b$-p(Leu) copolypeptide obtained from ROP of Lys(Z)-NCA and Leu-NTA ([M $]_{\mathrm{o}} /[\mathrm{I}]=111 ; 85.3 \% \mathrm{p}($ Lys-Z)). Integrations specific to the Lys- $\mathrm{Z}$ (a, representing $2 \mathrm{H}$ ) and leucine $(\mathbf{b}$, representing $6 \mathrm{H})$ side chains are shown. When the integration of peak $(\mathbf{b})$ is normalized to $6.00 \mathrm{H}$, the following equation holds true:

$\%$ Lysine in copolypeptide $=\frac{\text { peak a integration } \div 2 \mathrm{H}}{1+(\text { peak a integration } \div 2 \mathrm{H})} \times 100 \%$

\subsection{Determination of length of discrete p(Leu) block}

The number of repeated leucine residues involved in the discrete $p($ Leu $)$ block in a one-shot block copolypeptide is determined by ${ }^{1} \mathrm{H}-\mathrm{NMR}$ kinetics experiments. Here, comonomer concentration is monitored through the entire course of the copolymerization, as seen in Figure S5. The concentration of Leu-NTA at the point in which all Lys(Z)-NCA is consumed can be used to calculate the degree of polymerization (DP) of the discrete $\mathrm{p}(\mathrm{Leu})$ block at the $\mathrm{N}$-terminus of the copolypeptide by the following equation:

$$
\text { DP of discrete } \mathrm{p}(\text { Leu }) \text { block }=\frac{\text { mmol LeuNTA when Lys }(\mathrm{Z}) \mathrm{NCA} \text { is fully consumed }}{\text { mmol initiator }}
$$


(A)

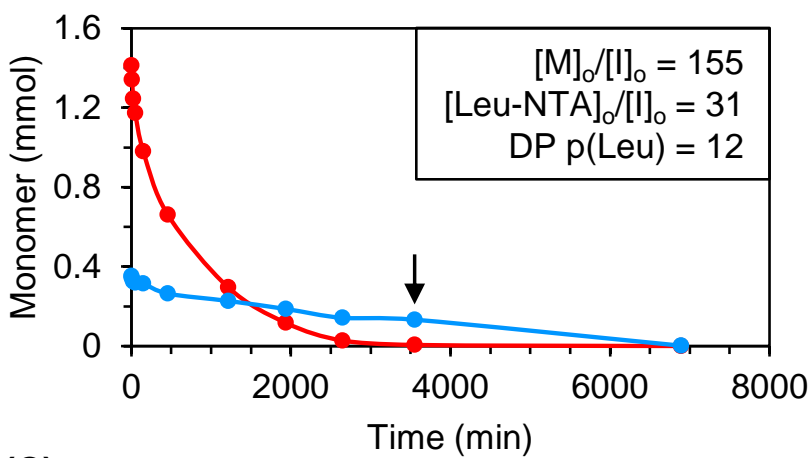

(C)

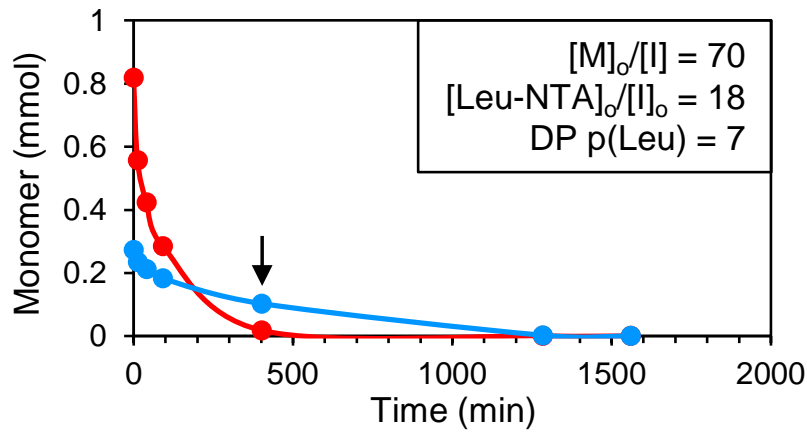

(B)

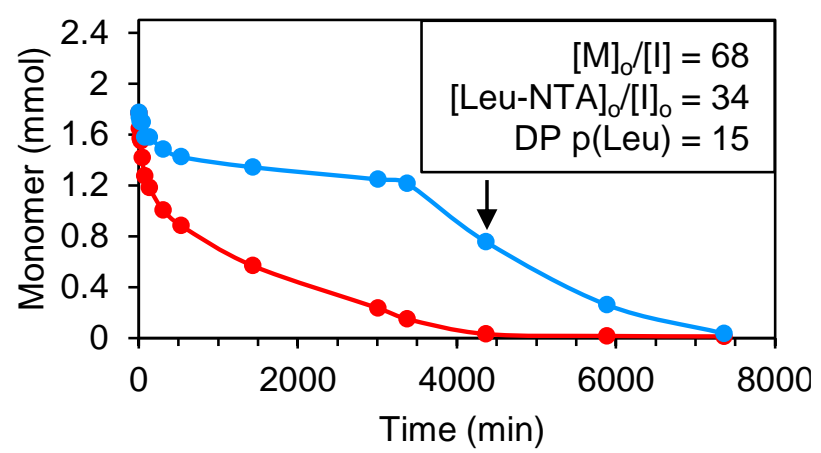

Legend

- Lys(Z)-NCA

- Leu-NTA

$\downarrow$ Point at which discrete $p($ Leu $)$ block begins to form

Figure S5. Comonomer consumption is monitored throughout the course of the copolymerization via ${ }^{1} \mathrm{H}-\mathrm{NMR}$ kinetics. This allows determination of the degree of polymerization of the discrete $\mathrm{p}(\mathrm{Leu})$ block (DP $\mathrm{p}(\mathrm{Leu})$ ). Kinetics experiment in panels A and C were conducted at under light vacuum pressure to speed up the polymerization. The kinetics experiment in panel B was conducted at standard pressure.

Since the length of the discrete $\mathrm{p}(\mathrm{Leu})$ block in a one-shot copolypeptide is dictated by both the $[\mathrm{M}]_{\mathrm{o}} /[\mathrm{I}]$ and the comonomer feed ratio, one must perform a kinetics experiment for each combination of these parameters in order to define the exact extent of tapering. However, it is reasonable to assume that the length of discrete $\mathrm{p}(\mathrm{Leu})$ block is proportional to the $[\mathrm{M}]_{\mathrm{o}} /[\mathrm{I}]$ for copolypeptides with the same feed ratio, given the first order nature of monomer consumption in this copolymerization. As such, the following equation can be used to estimate the DP of the discrete $\mathrm{p}(\mathrm{Leu})$ :

$$
(\text { DP of discrete } \mathrm{p}(\text { Leu }) \text { block })_{\mathrm{A}}=\frac{(\text { DP of discrete } \mathrm{p}(\text { Leu }) \text { block })_{\mathrm{B}} \times\left[\mathrm{M}_{\mathrm{O}} / \mathrm{I}\right]_{\mathrm{A}}}{\left[\mathrm{M}_{\mathrm{O}} / \mathrm{I}\right]_{\mathrm{B}}}
$$

Where copolypeptide A and copolypeptide B have the same comonomer feed ratio ([Leu$N T A]_{o} /[\text { Lys }(Z)-N C A]_{o}$ is equal for copolypeptide $A$ and $\left.B\right)$, and the DP of the discrete $p($ Leu $)$ block of copolypeptide $B$ is known through a kinetics experiment. 


\begin{tabular}{|c|c|c|c|}
\hline$[\mathrm{M}]_{\mathrm{o}} /[\mathrm{I}]$ & Feed ratio Leu-NTA & {$[\text { Leu-NTA }]_{\mathrm{o}} /[]_{\mathrm{o}}$} & $\begin{array}{c}\text { DP of discrete } \mathrm{p}(\text { Leu }) \\
\text { block }\end{array}$ \\
\hline 30 & $20 \%$ & 6 & 2 \\
\hline 70 & $20 \%$ & 14 & 5 \\
\hline 112 & $20 \%$ & 23 & 12 \\
\hline 149 & $20 \%$ & 30 & 34 \\
\hline 153 & $50 \%$ & 77 & 0 \\
\hline 150 & $0 \%$ & 0 & 9 \\
\hline
\end{tabular}

Table S1. The degree of polymerization (DP) of the discrete $\mathrm{p}$ (Leu) block at the N-terminus of the copolypeptides displayed in Figure 2 (main text) were calculated using representative comonomer conversion versus time plots given in Figure S5.

\subsection{Determination of PA-G/PA Composition}

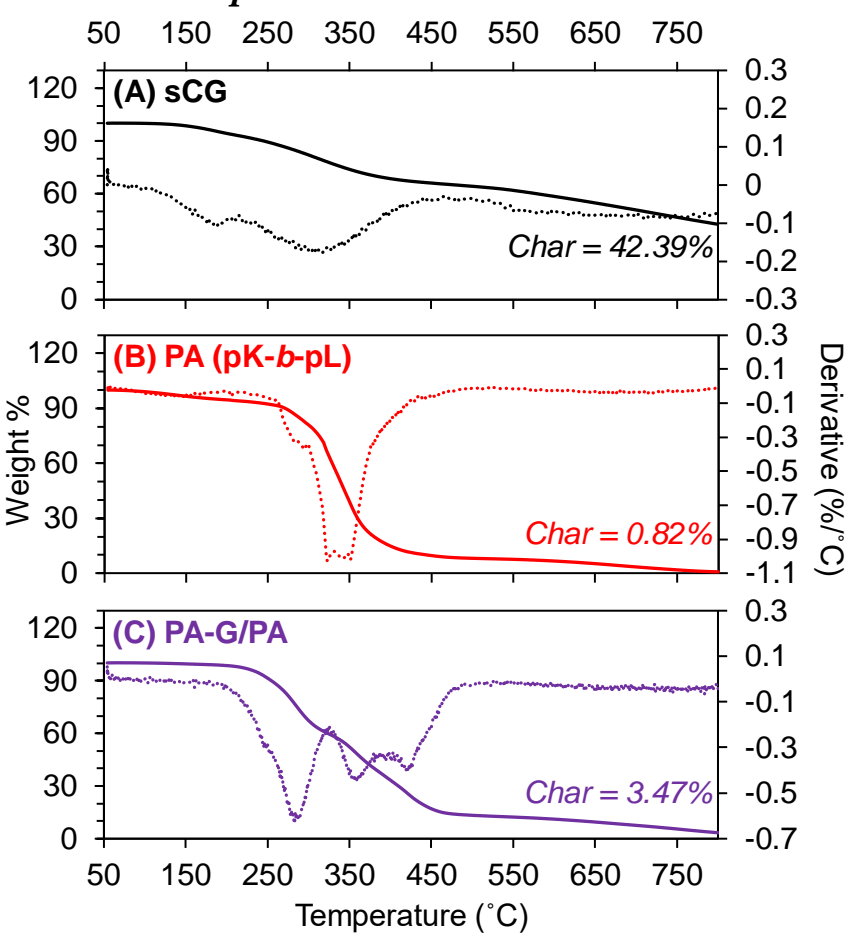

Figure S6. Thermogravimetric analysis of the PA-G/PA composite material (C) compared to parent materials, sCG (graphenic component, A) and PA (pK- $b$-pL, copolypeptide component, B). Char weights were used to calculate the composition of the PA-G/PA composite material. The data was used to analyze the mass contributions of the PA and graphenic components of the PA-G/PA composite. Using the system of equations outlined below, it was determined that the PA-G/PA composite is $93.61 \%$ PA and $6.39 \%$ graphenic by mass. 
First, the char weight for the PA had to be corrected for mass contributed from water adsorbed to the sample. The adsorbed water evaporated between $97.8-165.7{ }^{\circ} \mathrm{C}$ and contributed to $3.31 \%$ of the PA mass. To correct for the mass contribution of water, the char weight of the PA was recalculated using the following system of equations:

$$
\begin{gathered}
\% \text { Water }=\% \text { mass }_{97.8}{ }^{\circ} \mathrm{C}-\% \text { mass }_{165.7}{ }^{\circ} \mathrm{C}=99.12-95.81=3.31 \% \\
\% \text { Sample }=100-\% \text { Water }-\% \text { Char }_{\text {raw }}=100-3.31-0.79=95.90 \% \\
\% \text { Char }_{\mathrm{PA}, \text { corrected }}=\frac{\% \mathrm{Char}_{\text {raw }}}{\% \text { Sample }+\% \mathrm{Char}_{\text {raw }}} \times 100=\frac{0.79}{95.90+0.79} \times 100=0.82 \%
\end{gathered}
$$

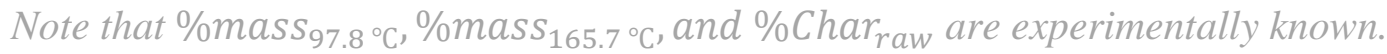

Next, char weights of PA-G/PA, sCG, and PA were determined experimentally by TGA (Figure S6) and used to calculate the weight percent of each component in the PA-G/PA composite using the following system of equations:

$$
\begin{gathered}
\% \mathrm{PA}+\% \text { Graphenic }=100 \\
\operatorname{Char}_{\mathrm{PA}-\mathrm{G} / \mathrm{PA}}=\left(\operatorname{Char}_{P A, \text { corrected }} \times \frac{\% \mathrm{PA}}{100}\right)+\left(\operatorname{Char}_{\mathrm{sCG}} \times \frac{\% \mathrm{Graphenic}}{100}\right)
\end{gathered}
$$

Note that Char ${\mathrm{PA}-\mathrm{G} / \mathrm{PA}, \text { Char }_{P A, \text { corrected, }} \text {, and Char }}_{S C G}$ are experimentally known.

\section{SUPPLEMENTAL RESULTS}

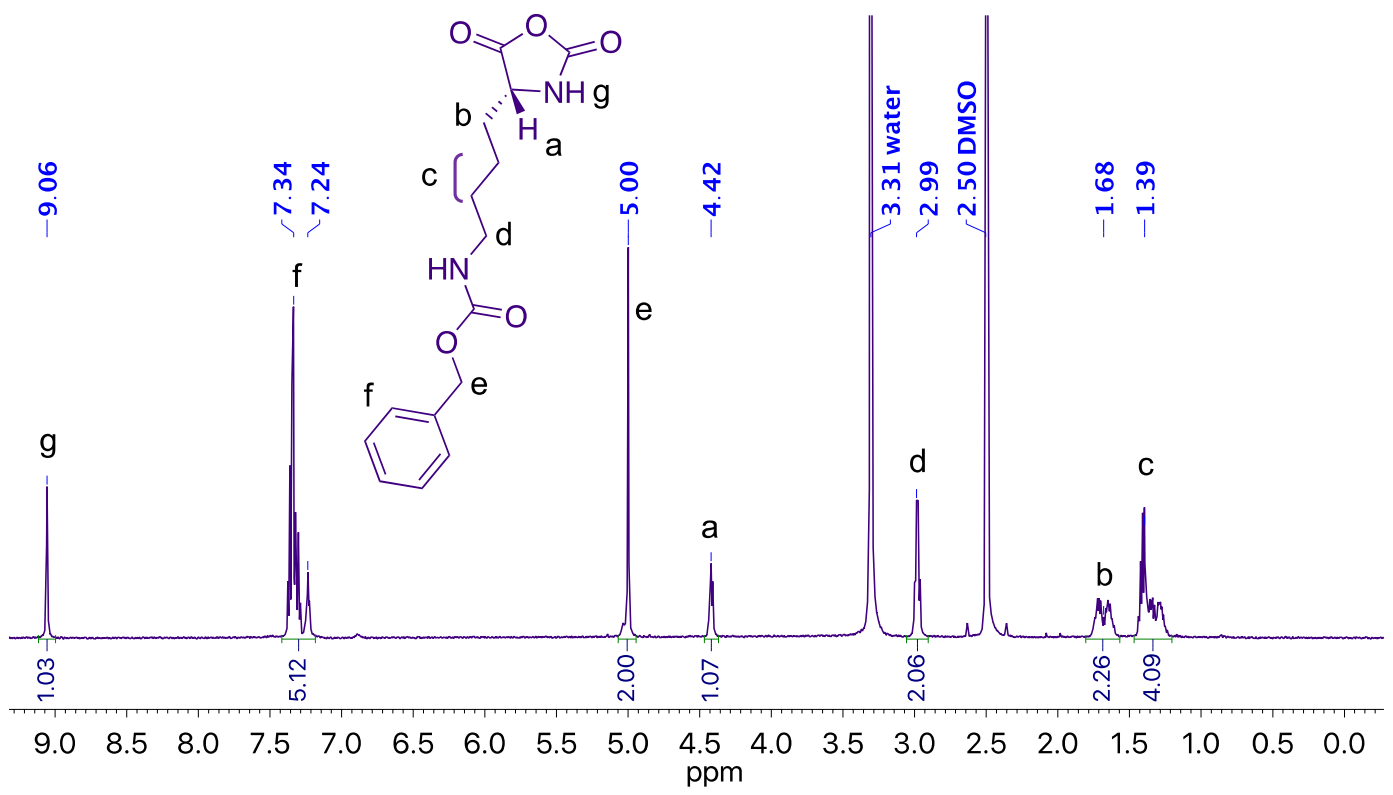

Figure S7. ${ }^{1} \mathrm{H}-\mathrm{NMR}(500 \mathrm{MHz})$ of Lys(Z)-NCA in DMSO-d 6 . 


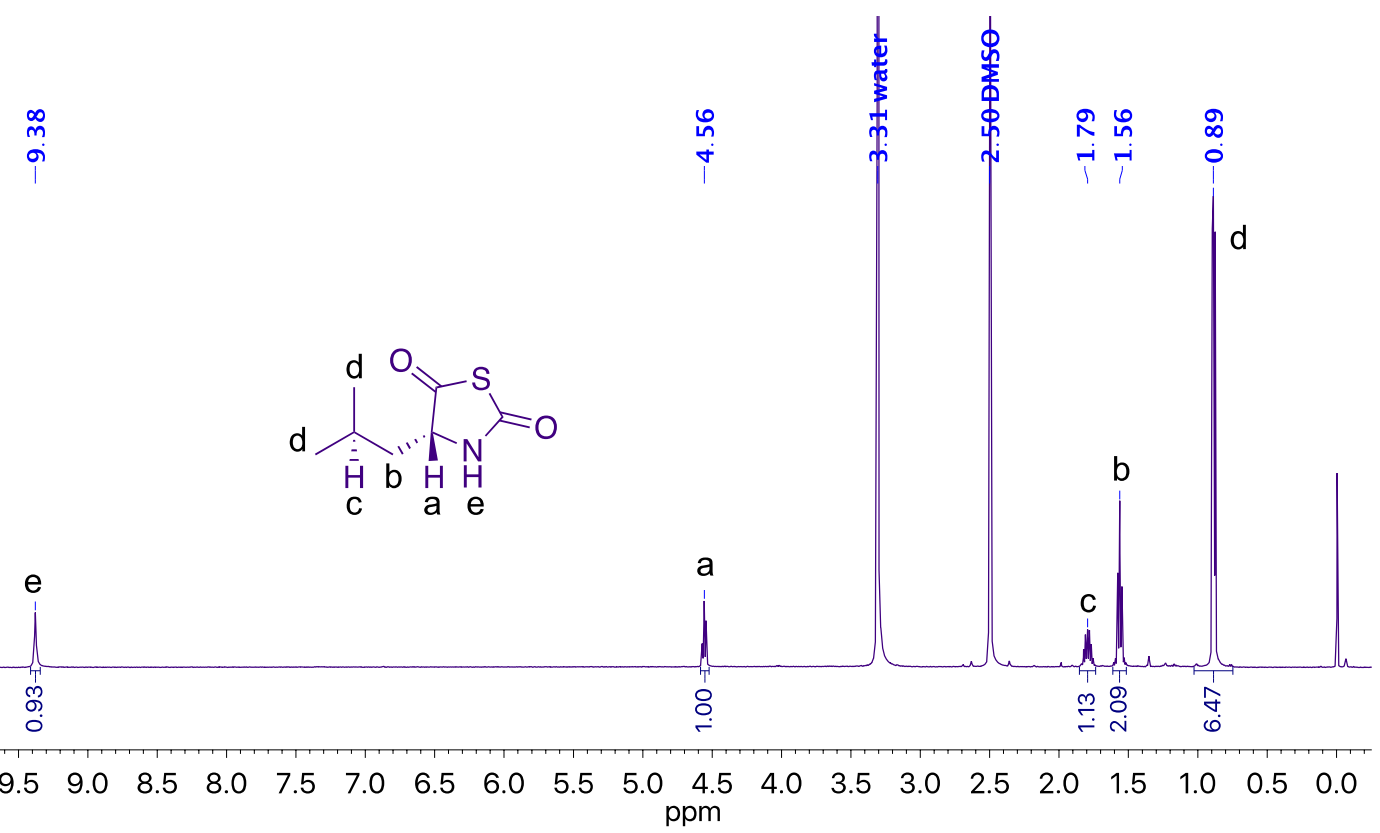

Figure S8. ${ }^{1} \mathrm{H}-\mathrm{NMR}(500 \mathrm{MHz})$ of Leu-NTA in DMSO-d 6.

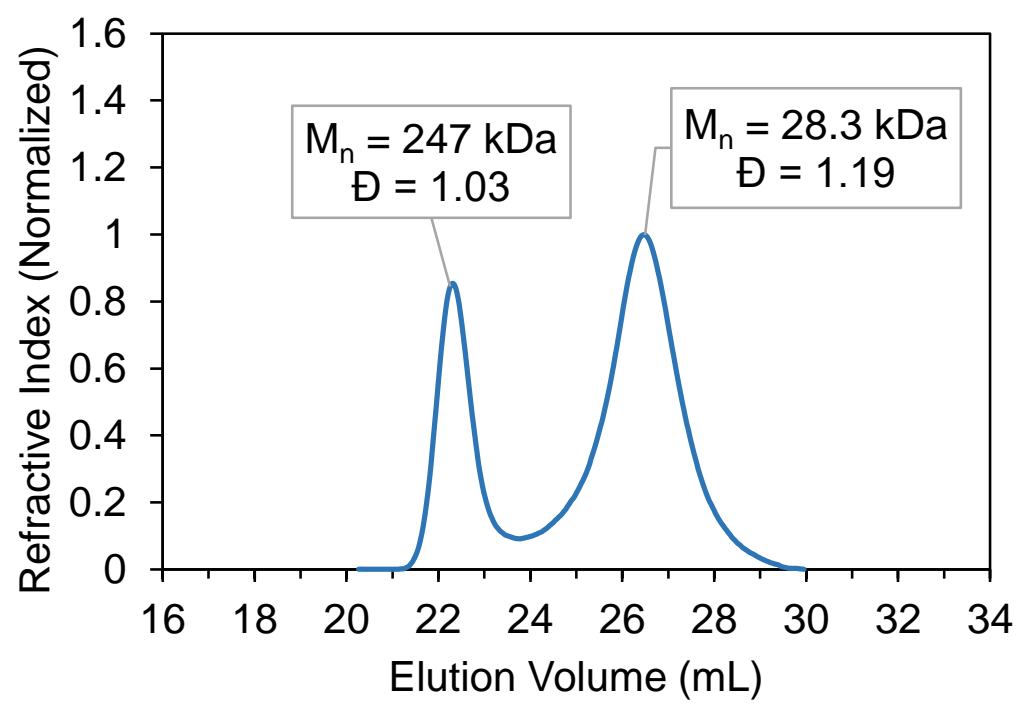

Figure S9. Gel permeation chromatography (GPC) of $\mathrm{p}(\text { Lys-Z) })_{100}-b-\mathrm{p}(\mathrm{Leu})_{40}$ (theoretical $\mathrm{M}_{\mathrm{n}}=$ $30.9 \mathrm{kDa}$ ) prepared by sequential NCA monomer addition with a primary amine initiator (hexylamine). The peak corresponding to a $\mathrm{M}_{\mathrm{n}}$ of $247 \mathrm{kDa}$ is likely due to the presence of copolypeptide aggregates. 
(A)

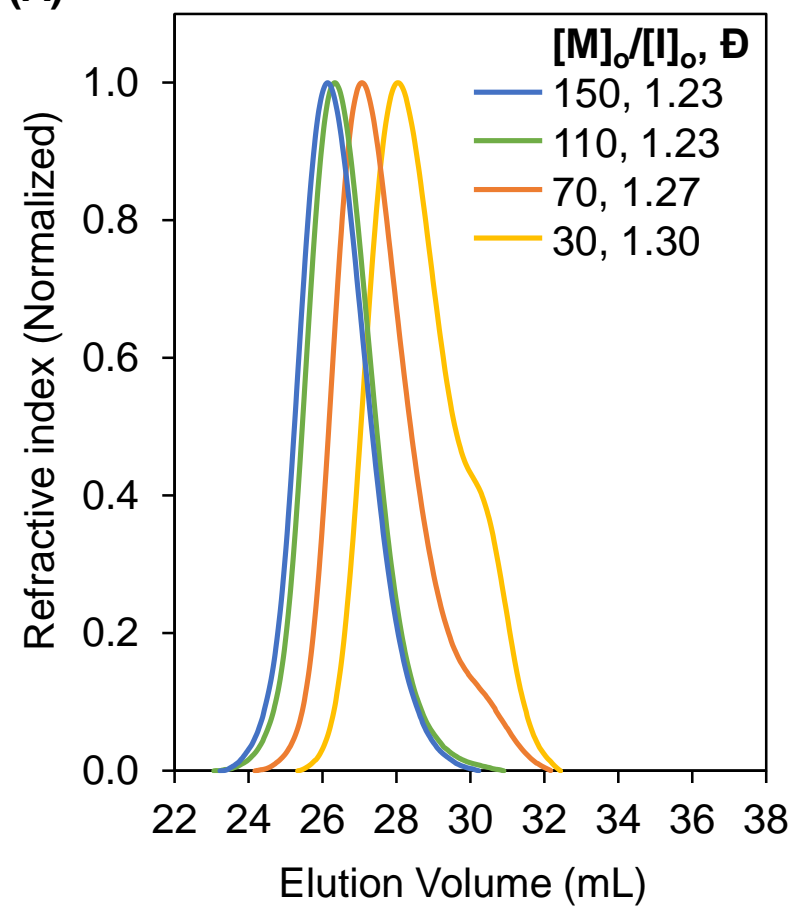

(B)

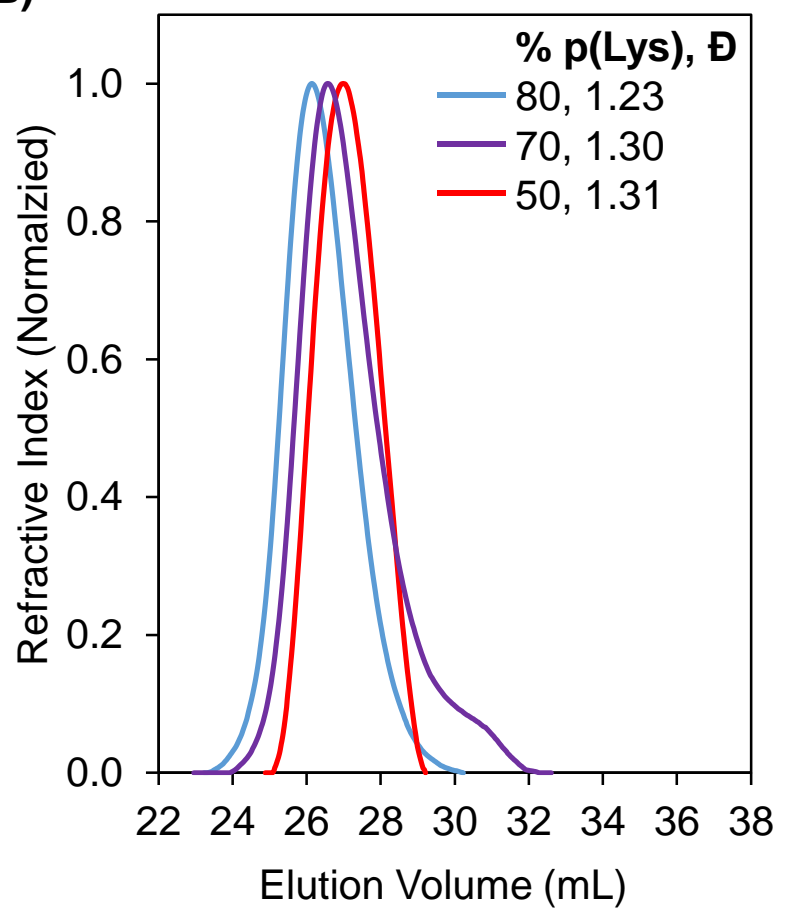

Figure S10. GPC of one-shot $\mathrm{p}(\mathrm{Lys}-\mathrm{Z})-b-\mathrm{p}$ (Leu) copolypeptides demonstrate unimodality and low dispersity of molecular weight. A) Comonomer feed ratio was $80 \%$ Lys(Z)-NCA and $20 \%$ LeuNTA for all polymerizations in A. In the $[\mathrm{M}]_{\mathrm{o}} /[\mathrm{I}]=30$ (yellow) and 70 (orange) copolypeptides, small shoulder at higher elution volume are due to the presence of mixed secondary structures. ${ }^{4} \mathbf{B}$ ) $[\mathrm{M}]_{0} /[\mathrm{I}]=150$ for all for all polymerizations in $\mathrm{B}$. 

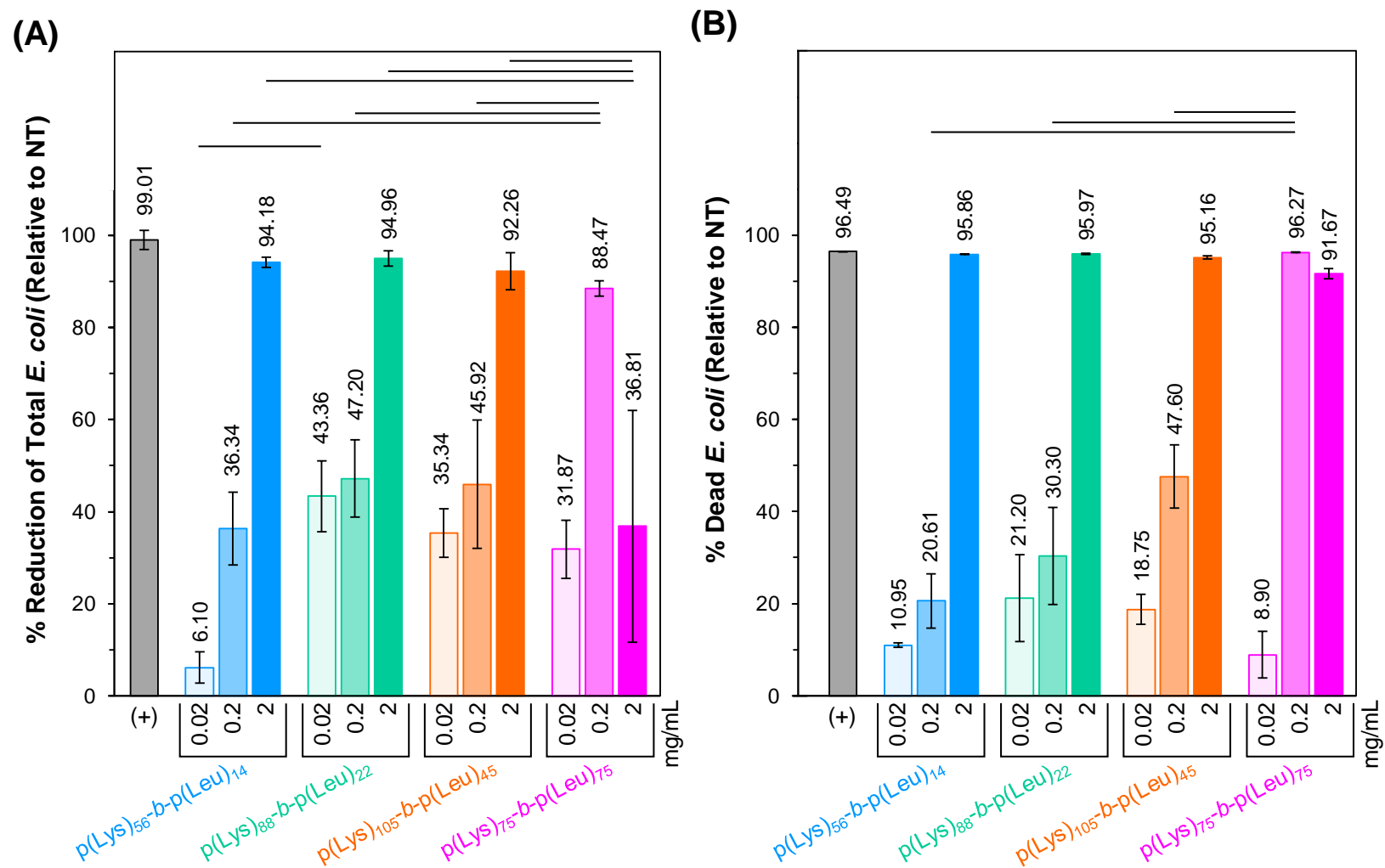

Figure S11. One-shot peptide amphiphiles (PAs) with different $\% \mathrm{p}(\mathrm{Leu})$ and molecular weight were evaluated for their ability to reduce proliferation and kill E. coli K12 bacteria. (A) The materials' bacteriostatic activity was evaluated as percent cell reduction normalized to the no treatment condition, which was defined as $0 \%$ reduction. (B) The materials' bactericidal activity was evaluated as percent dead bacteria (determined using the LIVE/DEAD BacLight Fluorescence assay) normalized to the no treatment condition, which was defined as $0 \%$ dead. The positive control (+) was $100 \mathrm{U} / \mathrm{mL}(\sim 60 \mu \mathrm{g} / \mathrm{mL})$ penicillin with $100 \mu \mathrm{g} / \mathrm{mL}$ streptomycin. Horizontal bars above graph indicate statistical significance $(\mathrm{p}<0.05)$. 


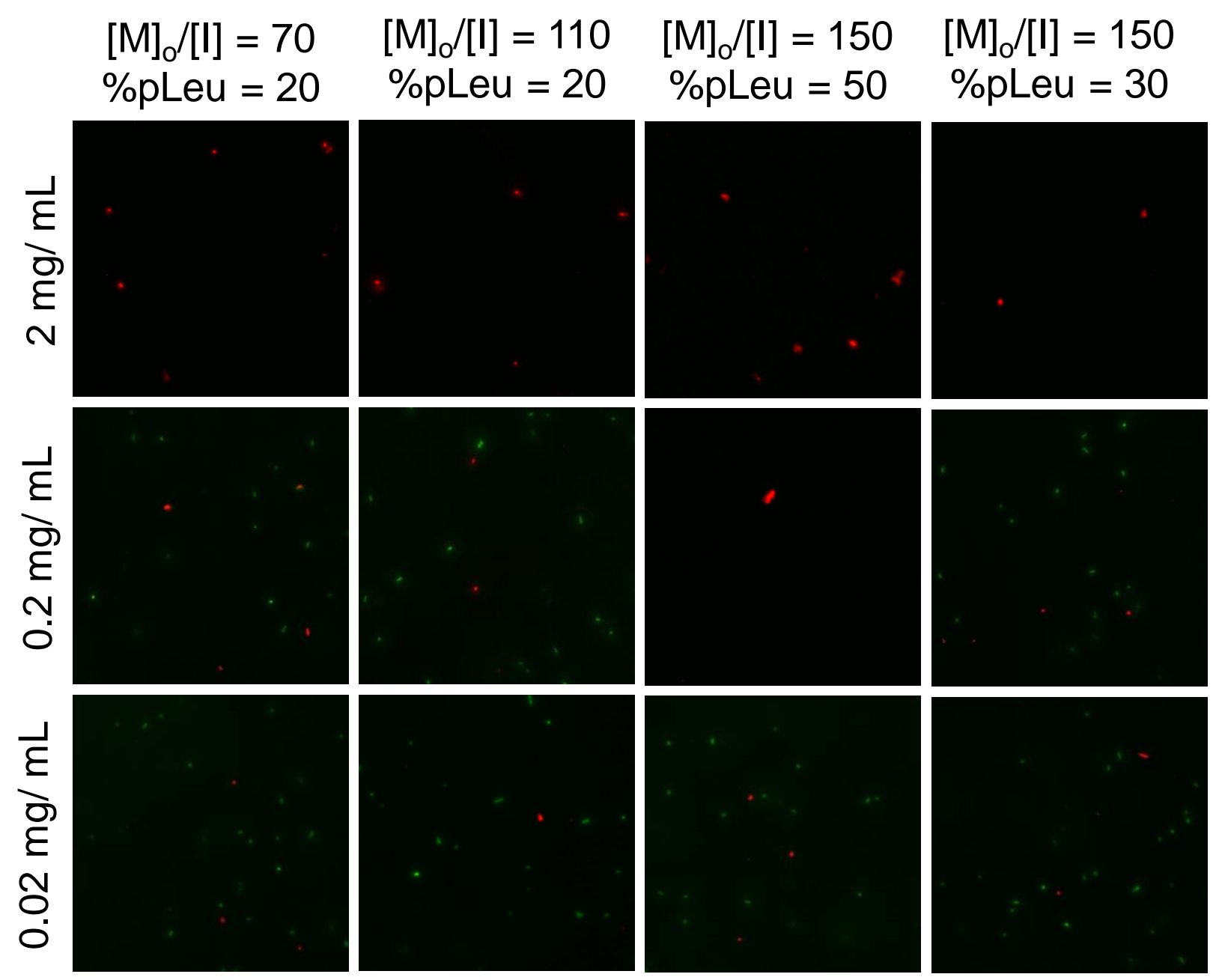

No treatment

(+) Control

$50 \mu \mathrm{m}$
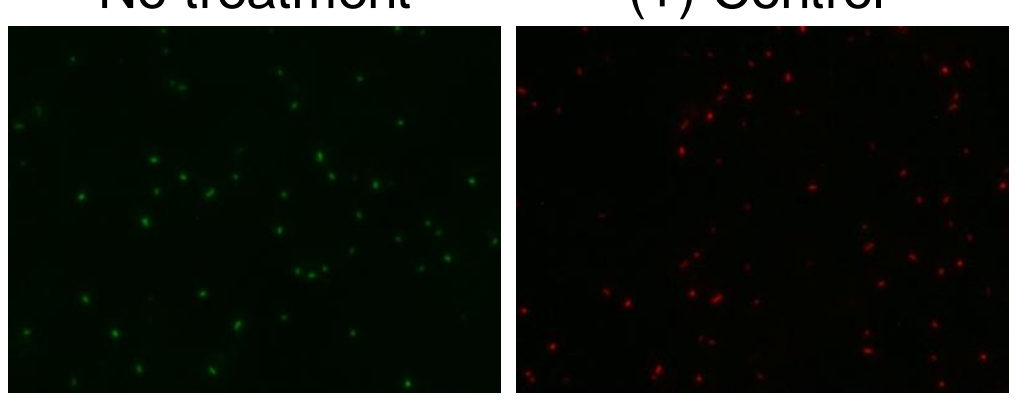

$50 \mu \mathrm{m}$

Figure S12. Fluorescence microscopy images of stained $E$. coli following $16 \mathrm{~h}$ exposure to various one-shot peptide amphiphiles. The positive (+) control was exposed to $100 \mathrm{U} / \mathrm{mL}$ penicillin with $100 \mu \mathrm{g} / \mathrm{mL}$ streptomycin. Green fluorescence indicates live cells, and red fluorescence indicates dead cells. 


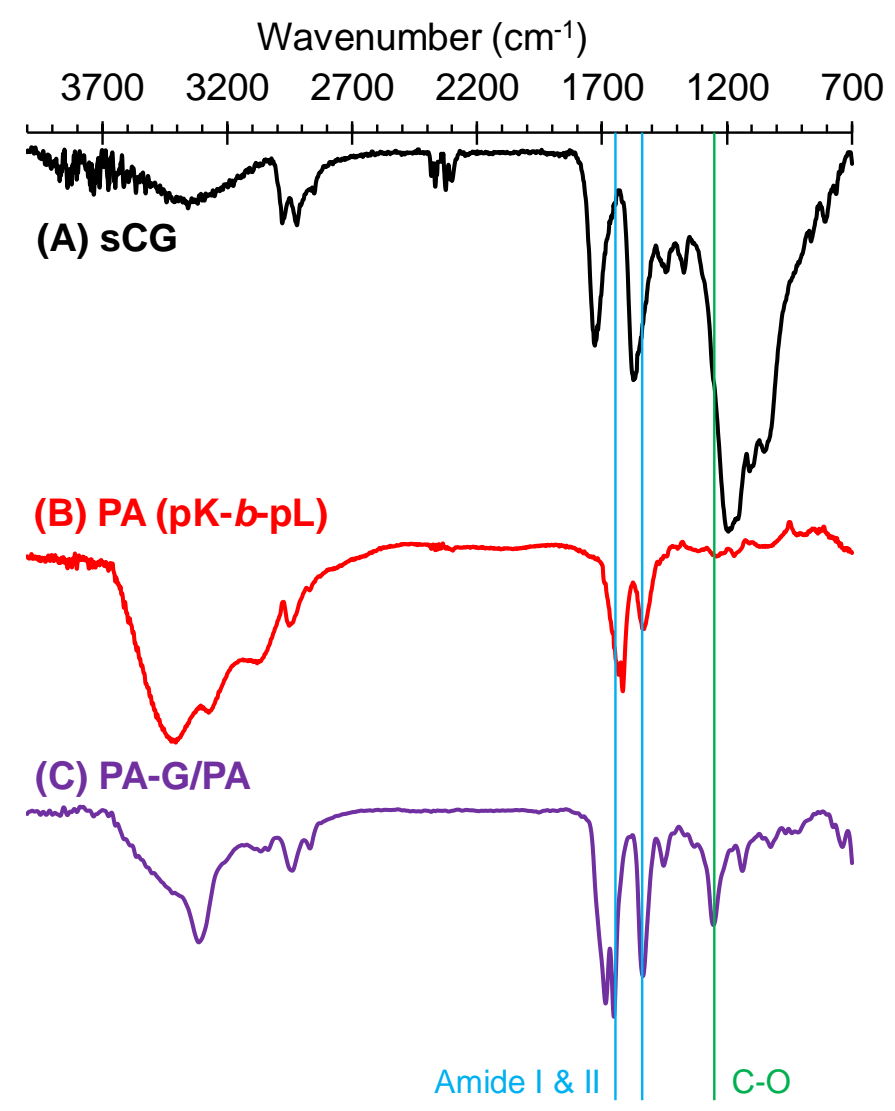

Figure S13. Fourier transform infrared spectroscopy demonstrates the presence of both the graphenic (sCG) and peptide amphiphile (PA) components in the PA-G/PA composite through the presence of both amides and C-O stretching. The parent graphenic material, sCG (small Claisen graphene) contains $\mathrm{C}-\mathrm{O}$ stretching with no amides (A). The parent PA material (pK- $b-\mathrm{pL})$ contains amides with no C-O stretching (B).

\section{BACTERIAL STUDIES}

\subsection{Bacterial Culture}

\section{Preparation of Buffered Media}

Media was prepared by dissolving $12.5 \mathrm{~g}$ of LB Miller Broth (Fisher BioReagents ${ }^{\mathrm{TM}}$, USA) and $0.75 \mathrm{~g}$ of Tris $\mathrm{HCl}$ (Promega, Madison, WI, USA) in $500 \mathrm{~mL}$ of $\mathrm{DI}_{2} \mathrm{O}$ to give a final media concentration of $10 \mathrm{~g} \mathrm{~L}^{-1}$ tryptone, $10 \mathrm{~g} \mathrm{~L}^{-1} \mathrm{NaCl}$, and $5 \mathrm{~g} \mathrm{~L}^{-1}$ yeast extract. Media was then autoclaved at $121{ }^{\circ} \mathrm{C}$ for $1 \mathrm{~h}$. Media was cooled to room temperature before use.

\section{Bacterial Culture}

In a $50 \mathrm{~mL}$ centrifuge tube with a loosened cap, Escherichia coli (E. coli) strain K12 (ATCC® $25404^{\mathrm{TM}}$ ) was propagated in $5 \mathrm{~mL}$ of buffered media with rotational shaking (MiniMixer $^{\mathrm{TM}}$, Benchmark Scientific, Sayreville, NJ, USA) for $16 \mathrm{~h}$ at $37^{\circ} \mathrm{C}$ (MyTemp Mini Digital Incubator, Benchmark Scientific). Then, bacteria were centrifuged at $10000 \times g$ for $15 \mathrm{~min}$ to pellet the cells, followed by aspiration of the supernatant and resuspension of the pellet in $5 \mathrm{~mL}$ of fresh, buffered 
media. Cultures were then used for experiments in a 1:5 split ratio (1 mL stock cell suspension + $4 \mathrm{~mL}$ fresh, buffered media).

Peptide amphiphiles (PAs) were weighed into $1.5 \mathrm{~mL}$ Eppendorf tubes and sterilized by irradiating with ultraviolet light $(254 \mathrm{~nm})$ for 5 minutes. PAs were then dissolved in buffered media to give a final concentration of $4 \mathrm{mg} \mathrm{mL}^{-1}$. These PA solutions were serial diluted to give concentrations of $0.4 \mathrm{mg} \mathrm{mL}^{-1}$ and $0.04 \mathrm{mg} \mathrm{mL}^{-1}$.

These PA solutions were combined with fresh, buffered media and 1:5 split ratio to give PA concentrations of 2, 0.2 , and $0.02 \mathrm{mg} \mathrm{mL}^{-1}$ and an E. coli concentration of $4 \% \mathrm{v} / \mathrm{v}$ from the 1:5 split ratio. The positive control contained Penicillin/Streptomycin (ThermoFisher Scientific) diluted to $100 \mathrm{U} \mathrm{mL}^{-1}$ penicillin (approximately $60 \mu \mathrm{g} / \mathrm{mL}$ ) and $100 \mu \mathrm{g} / \mathrm{mL}$ streptomycin with 4\% v/v E. coli from the 1:5 split ratio. The "no treatment" (NT) control contained only 4\% v/v E. coli from the 1:5 split ratio and buffered media. In a $96-$ well plate, $250 \mu \mathrm{L}$ of each sample was dispensed into the interior wells. All samples were run in triplicate. The 96-well plate (with cell culture plate lid) was incubated at $37^{\circ} \mathrm{C}$ on a rotational shaker for $16 \mathrm{~h}$.

After incubation, $125 \mu \mathrm{L}$ was removed from each well and dispensed into a $1.5 \mathrm{~mL}$ snap-top Eppendorf tube, then centrifuged (Eppendorf Microcentrifuge Model 5430) at $10000 \times g$ for 10 min to pellet bacteria. The supernatant was carefully aspirated, and the bacterial pellet was redispersed in $1.0 \mathrm{~mL}$ of sterile $0.85 \% \mathrm{NaCl}$ buffer. Then, $100 \mu \mathrm{L}$ was dispensed into a new 96 -well plate. This plate was analyzed by absorbance, fluorescence, and microscopy.

\subsection{Data Analysis}

\section{Absorbance/Fluorescence}

The 96-well culture plate containing bacterial dispersions was analyzed using a Spark® plate reader (Tecan) with SparkControlTM v2.2 software. Absorbance was measured from 200-1000 $\mathrm{nm}$ with a step size of $1 \mathrm{~nm}$. Absorbance at $600 \mathrm{~nm}$ (OD600) was used as an indicator of biomass, and thus, cell proliferation. Here, "\% Reduction of Total E. coli (Relative to NT)" (Figure S11A) was calculated using the following equation:

$(\% \text { Reduction of Total } E \text {. coli })_{\text {sample }}=100-\left(\frac{(\text { OD600 }}{\left.\text { sample }-0 D 600_{\text {blank }}\right)}-100\right)$

Where $\mathrm{OD} 600_{\text {sample }}=$ the absorbance at $600 \mathrm{~nm}$ of any given test sample, $\mathrm{OD}_{600}$ blank $=$ the absorbance at $600 \mathrm{~nm}$ of the blank, $0.85 \% \mathrm{NaCl}$ with no cells, and $\mathrm{OD}_{600} \mathrm{NT}=$ the absorbance at $600 \mathrm{~nm}$ of the no treatment condition

Next, a modified procedure for the microplate LIVE/DEAD $®$ BacLight ${ }^{\mathrm{TM}}$ Bacterial Viability assay (Thermo Fisher) was used. ${ }^{5}$ Briefly, the LIVE/DEAD® BacLight ${ }^{\mathrm{TM}}$ stain solution was prepared by dispersing $3 \mu \mathrm{L}$ of Syto ${ }^{\circledR} 9$ and $3 \mu \mathrm{L}$ of propidium iodide for every $2 \mathrm{~mL}$ of $\mathrm{DI} \mathrm{H}_{2} \mathrm{O}$. Then, $100 \mu \mathrm{L}$ of the stain solution was added into each well of the 96-well culture plate containing $100 \mu \mathrm{L}$ of sample. The plate was protected from light and incubated for $15 \mathrm{~min}$ at room temperature. 
Fluorescence data for all samples stained with the LIVE/DEAD® BacLight ${ }^{\mathrm{TM}}$ assay was collected on a Spark ${ }^{\circledR}$ plate reader with SparkControlTM v2.2 software. Emission spectra were acquired from 500-700 $\mathrm{nm}$ with a $5 \mathrm{~nm}$ step size using an excitation wavelength of $485 \mathrm{~nm}$ with a bandwidth of $10 \mathrm{~nm}$ and a manual gain of 60 from a z-position of $17,530 \mu \mathrm{m}$. Here, "\% Dead E. coli (Relative to NT)" (Figure S11B) was calculated using the following equation:

$$
(\% \text { Dead } E \text {. coli })_{\text {sample }}=100-\left(\frac{\left(\frac{E m_{530}}{E m_{630}}\right)_{\text {sample }}}{\left(\frac{E m_{530}}{E m_{630}}\right)_{\mathrm{NT}}} * 100\right)
$$

Where $\mathrm{Em}_{530}=$ the emission intensity at $530 \mathrm{~nm}$ (measuring live E. coli),

$\mathrm{Em}_{630}=$ the emission intensity at $630 \mathrm{~nm}$ (measuring dead E. coli),

$\left(\mathrm{Em}_{530} / \mathrm{Em}_{630}\right)_{\text {sample }}=$ the live/dead ratio of any given test sample,

and $\left(\mathrm{Em}_{530} / \mathrm{Em}_{630}\right)_{\mathrm{NT}}=$ the live/dead ratio of the no treatment condition

The "\% Reduction of Total E. coli" and "\% Dead E. coli" data points were used to calculate "\% Reduction of Live E. coli" (Figure 4, main text) using the following equation:

(\%Reduction of Live E. Coli) sample

$$
=100-\left((\% \text { Total } E . \text { coli })_{\text {sample }} * \frac{(\% \text { Live } E \text {. coli })_{\text {sample }}}{100}\right)
$$

Where $(\% \text { Total E. coli })_{\text {sample }}=100-(\% \text { Reduction of Total E. coli })_{\text {sample }}$ and $(\% \text { Live } E \text {. coli })_{\text {sample }}=100-(\% \text { Dead Total } E \text {. coli })_{\text {sample }}$

\section{Microscopy (Bacterial)}

Fluorescence microscopy images (Figure S12) were collected using an EVOS® FL Auto Cell Imaging System (ThermoFisher Scientific) with a 40×, 0.65 numerical aperture objective. Samples were prepared by depositing $10 \mu \mathrm{L}$ of stained bacteria onto a $25 \times 75 \mathrm{~mm}, 1.0 \mathrm{~mm}$ thick microscope slide. After depositing bacterial samples on the slide, samples were left for 2-5 minutes to allow bacteria to settle onto the microscope slide for co-localization fluorescence imaging. Fluorescence images were acquired using the GFP (470/22 Ex; 510/42 Em) and RFP (531/40 Ex; 593/40 Em) light cubes, and phase contrast images were acquired at the same imaging parameters across all samples.

\subsection{Statistical Analysis}

Bacterial absorbance and fluorescence assays were tested in three independent cultures $(n=3)$. Data in Figure 4 (main text) and Figure S11 is presented as the average \pm standard deviation (SD). Statistical analysis was performed using IBM SPSS Statistics 26. One-way analysis of variance was performed; and if significant differences were detected, we performed post hoc Bonferroni and Tukey tests. $P<0.05$ was deemed statistically significant. 


\section{REFERENCES}

(1) Cao, J.; Siefker, D.; Chan, B. A.; Yu, T.; Lu, L.; Saputra, M. A.; Fronczek, F. R.; Xie, W.; Zhang, D. Interfacial Ring-Opening Polymerization of Amino-Acid-Derived $N$ -

Thiocarboxyanhydrides Toward Well-Defined Polypeptides. ACS Macro Lett. 2017, 6 (8), 836-840. https://doi.org/10.1021/acsmacrolett.7b00411.

(2) Sydlik, S. A.; Swager, T. M. Functional Graphenic Materials Via a Johnson-Claisen Rearrangement. Adv. Funct. Mater. 2013, 23 (15), 1873-1882. https://doi.org/10.1002/adfm.201201954.

(3) Eckhart, K. E.; Holt, B. D.; Laurencin, M. G.; Sydlik, S. A. Covalent Conjugation of Bioactive Peptides to Graphene Oxide for Biomedical Applications. Biomater. Sci. 2019, 7 (9), 3876-3885. https://doi.org/10.1039/C9BM00867E.

(4) Huesmann, D.; Birke, A.; Klinker, K.; Türk, S.; Räder, H. J.; Barz, M. Revisiting Secondary Structures in NCA Polymerization: Influences on the Analysis of Protected Polylysines. Macromolecules 2014, 47 (3), 928-936. https://doi.org/10.1021/ma5000392.

(5) LIVE/DEAD BacLight Bacterial Viability Kit Protocol https://assets.thermofisher.com/TFS-Assets/LSG/manuals/mp07007.pdf (accessed Jun 10, 2019). 